\title{
KARAKTERISTIK SERAT NANO KOMPOSIT KITOSAN-POLIVINIL ALKOHOL (PVA) DARI CANGKANG RAJUNGAN MELALUI PROSES ELECTROSPINNING
}

\section{Production of Chitosan-Polyvinyl Alcohol (PVA) Composite Nanofiber by Electrospinning Method}

\author{
Muhamad Darmawan*, Syamdidi, Yusma Yennie dan Singgih Wibowo \\ Pusat Penelitian dan Pengembangan Daya Saing Produk dan Bioteknologi Kelautan dan Perikanan, \\ JI. KS Tubun Petamburan VI, Jakarta Pusat, Indonesia \\ * Korespondensi Penulis: m.darmawan22@gmail.com \\ Diterima: 1 Agustus 2016; Disetujui: 18 Nopember 2016
}

\begin{abstract}
ABSTRAK
Kitosan merupakan salah satu polimer alam yang dapat digunakan sebagai bahan pembuat serat nano. Namun demikian, serat nano yang dibuat dari kitosan saja tidak memiliki karakteristik yang baik sehingga perlu dicampur dengan polimer sintetis lain seperti polivinil alkohol (PVA). Penelitian ini dilakukan untuk mempelajari karakteristik serat nano yang dibuat dari komposit kitosan cangkang rajungan dengan derajat deasetilasi $89,06 \%$ dan PVA menggunakan metode electrospinning. Perbandingan campuran kitosan-PVA yang digunakan adalah 1:9, 2:8, 3:7, dan 4:6 (v/v). Parameter yang diamati adalah karakteristik kitosan yang digunakan (derajat deasetilasi, kadar air, kadar abu, total N, viskositas, analisis gugus fungsi menggunakan FTIR), dan karakteristik serat nano yang dihasilkan (viskositas, struktur morfologi menggunakan scanning electron microscopy-SEM, dan analisis gugus fungsi menggunakan FTIR). Hasil penelitian menunjukkan bahwa struktur serat nano komposit kitosan-PVA yang dihasilkan masih menunjukkan adanya gumpalan-gumpalan (beads). Peningkatan jumlah kitosan dalam larutan kitosan-PVA meningkatkan jumlah gumpalan (beads) pada serat nano yang dihasilkan. Peningkatan jumlah PVA di dalam komposit meningkatkan viskositas larutan kitosan-PVA. Hasil dari FTIR menunjukkan adanya interaksi intermolekular antara PVA dan kitosan yang diduga melalui ikatan hidrogen.
\end{abstract}

KATAKUNCl： kitosan, polivinil alkohol, serat nano, komposit, electrospinning

ABSTRACT

Chitosan is one of the natural polymers that can be used as material for nanofiber. Nanofiber made from chitosan alone could not produce a good nanofiber characteristic. Chitosan has to be mixed with other synthetic polymers such as polyvinyl alcohol (PVA). This research is carried out to study the characteristics of nanofiber made from swimming crab shell chitosan (DD of 89.06\%)PVA composite using electrospinning method. The chitosan-polyvinyl alcohol (chitosan-PVA) ratios were 1:9, 2:8, 3:7, and 4:6 ( $/ \mathrm{v})$. The parameters observed were the characteristics of chitosan (degree of deacetylation, moisture, ash, $N$ total, viscosity, and functional group analysis using FTIR), and nanofiber characteristics (viscosity, morphological structure using scanning electron microscopy-SEM, and functional group analysis using FTIR). The results revealed that the structure of nanofibers produced still showed several beads. Addition of chitosan in the solution produced more beads in the nanofiber. The higher amount of PVA in the solution increased the viscosity of the solution of chitosan-PVA. FTIR data demonstrated a good intermolecular interaction between PVA and chitosan possibly due to hydrogen bonds.

KEYWORDS: chitosan, polyvinyl alcohol, nanofiber, composite, electrospinning. 


\section{PENDAHULUAN}

Penelitian terkait serat nano berbahan dasar biopolimer mulai banyak dilakukan pada dekade terakhir ini. Dalam dunia perdagangan, serat nano adalah serat yang mempunyai diameter kurang dari 0,5 mikron $(500 \mathrm{~nm})$, sedangkan serat nano yang telah diproduksi dan diperdagangkan mempunyai diameter antara $50 \mathrm{~nm}$ sampai $300 \mathrm{~nm}$ (Lee, 2007). Serat nano dari suatu bahan polimer dibuat dan diteliti dikarenakan memiliki sifat spesifik seperti permukaannya yang luas, ukuran pori yang kecil dan kemungkinannya untuk dibentuk struktur tiga dimensi sehingga berpotensi untuk digunakan sebagai media filtrasi, serat optik, pakaian pelindung (protective clothing), sistem penghantaran obat (drug delivery) dalam bidang farmasi (Herdiawan, Juliandri \& Nasir, 2013). Dalam aplikasinya di bidang biomedis, serat nano dapat digunakan sebagai bahan penyembuh luka atau wound dressing (Cai et al., 2010; Panboon, 2005), sebagai media untuk pembentukan jaringan lunak (tissue scaffold) (Herdiawan et al., 2013; Kumbar, James, Nukavarapu \& Laurencin, 2008) dan membantu dalam proses regenerasi tulang (Kim, Lee \& Knowles, 2006).

Teknik pembuatan serat nano dapat dilakukan dengan 3 cara, yaitu drawing, template synthesis, dan electrospinning. Teknik drawing yaitu teknik pembuatan serat nano dengan menyentuhkan mikropipet pada droplet dan menariknya. Teknik template synthesis yaitu pembuatan serat nano dengan menekan larutan polimer pada celah membran yang kecil untuk menghasilkan serat nano. Elektrospinning yaitu pembuatan serat nano dengan memberi muatan pada larutan polimer yang kemudian dijatuhkan dari pipet di dalam daerah bermedan listrik tinggi (Ramakrishna, Fujihara, Teo, Lim \& Ma, 2005). Brown dan Stevens (2007) menjelaskan bahwa electrospinning adalah teknik pembuatan serat nano dengan memanfaatkan gaya elektrostatik sebagai pendorong larutan polimer ketika larutan disuntikkan dari sebuah jarum (spineret) ke suatu kolektor. Pancaran larutan polimer berakselerasi ke arah kolektor memanjang dan menyebar secara tidak beraturan dari spineret ke kolektor. Pancaran larutan tersebut akan menipis dan mengering seiring dengan menguapnya pelarut, meninggalkan serat-serat nano yang saling berhubungan satu dengan lainnya membentuk jaring-jaring yang solid (webs). Di antara beberapa teknik yang dikembangkan dalam pembuatan serat mikro maupun nano, teknik electrospinning merupakan teknik yang dinilai lebih mudah dan efektif untuk membuat serat halus dari berbagai macam polimer sintetik maupun alami (Jayaraman, Kotaki, Zhang, Mo \& Ramakrishna, 2004).
Kitosan merupakan salah satu biomaterial yang digunakan dalam pembuatan serat nano dengan menggunakan teknik electrospinning ( $\mathrm{Ma}$, Yang, \& Chen, 2010). Kitosan dipilih karena memiliki biokompatibilitas dan biodegradabilitas tinggi serta bersifat polikationik yang dapat mengikat protein dengan mudah (Lee, Uyama \& Kwon, 2009). Di samping sifat di atas, kitosan juga memiliki kemampuan sebagai antimikroba sehingga digunakan dalam bidang biomedik seperti antimikroba untuk mencegah dan mengobati infeksi (Dai, Tanaka, Huang \& Hamblin, 2011) serta pembuatan wound dressing (Jayakumar, Prabaharan, Nair \& Tamura, 2010).

Pembuatan serat nano kitosan dengan bahan baku kitosan tanpa penambahan bahan atau polimer lain menghasilkan serat yang mudah putus dan sering banyak terdapat gumpalan (beads) di dalam serat yang terbentuk (Sun \& Li, 2011). Penambahan polimer lain seperti polyvinyl alcohol(PVA), poly-ethylene oxide (PEO), poly-ethylene terpthalate (PET), poly-capro lactone (PCL), dan poly-lactic acid (PLA) dapat digunakan untuk membuat serat nano kitosan menjadi lebih baik karena mampu meningkatkan kemampuan serat nano seperti sifat mekanik, biokompatibilitas, antibakteri dan sifat serat nano kitosan lainnya (Sun \& Li, 2011).

Salah satu pilihan polimer tambahan adalah PVA yang merupakan polimer sintetik hidrofilik, biodegradabel dan biokompatibel yang telah banyak digunakan di dalam bidang biomedik (Paradossi et al. 2003). Menurut Jiang, Liu dan Feng (2011), PVA merupakan biomaterial yang potensial untuk digunakan dalam proses kultur sel pembuluh darah. Hoffman (2002) telah berhasil menggunakan hidrogel yang dibuat dari PVA untuk kultivasi sel hidup. PVA bersifat kompatibel secara hayati dan sesuai untuk simulasi jaringan alami. Selain itu, PVA mempunyai permeabilitas oksigen yang baik, tidak bersifat imunogenik, dan memiliki sifat yang sangat baik dalam pembentukan film, pengemulsi dan dapat dilembabkan (Gessner \& Hawley, 1981).

Beberapa penelitian terkait pembuatan serat nano berbahan dasar kitosan telah dilakukan. Jia et al. (2007) melakukan pembuatan nano fiber komposit kitosan dan PVA (rasio 10:90; 20:80; 25:75; dan $30: 70(\mathrm{v} / \mathrm{v}))$ dengan derajat deasetilasi kitosan $78 \%$. Hasil penelitian menunjukkan adanya pengaruh dari rasio kitosan dan PVA terhadap morfologi serat nano yang dihasilkan. Cai et al. (2010) membuat serat nano sebagai bahan wound dressing dengan menggunakan komposit kitosan (Sigma-Aldrich, DD derajat deasetilasi $75-85 \%$ ) dan serat sutra. Wahyudi dan Sugiyana (2011) membuat serat nano menggunakan metoda electrospinning dengan bahan kitosan, PVA, 
dan nilon-6. Bahan baku kitosan yang digunakan berasal dari limbah cangkang udang. Bahan PVA dan nilon-6 mampu menghasilkan serat nano, sedangkan penggunaan kitosan tidak mampu membentuk serat nano. Judawisastra, Winiati dan Ramadhianti (2012) telah melakukan penelitian pembuatan serat nano kitosan tanpa beads melalui penambahan PVA dan hexadecylamine (HDA). Kitosan yang digunakan berbahan dasar dari limbah udang dengan derajat deasetilasi $65 \%$. Jenis bahan baku untuk kitosan berpengaruh terhadap karakteristik kitosan yang dihasilkan (Syamdidi \& Wibowo, 2012; Wibowo, 2003) seperti perbedaan antara kitosan dari cangkang rajungan dan cangkang udang, terutama viskositas dan DD nya. Perbedaan tersebut diduga akan berpengaruh terhadap karakteristik serat nano yang dihasilkan.

Mempertimbangkan hasil penelitian sebelumnya, dalam penelitian ini dipelajari pembuatan serat nano dari komposit kitosan dan PVA menggunakan teknik electrospinning dengan bahan baku kitosan yang berasal dari cangkang rajungan hasil penelitian Puslitbang Daya Saing Produk dan Bioteknologi Kelautan dan Perikanan (P3DSPBKP) dengan harapan dapat dihasilkan serat nano dengan kualitas yang lebih baik. Penelitian ini bertujuan untuk mempelajari karakteristik serat nano yang dibuat dari komposit kitosan cangkang rajungan dan PVA dengan beberapa variasi konsentrasi larutan.

\section{BAHAN DAN METODE}

\section{Bahan}

Bahan yang digunakan adalah kitosan yang dibuat dari cangkang rajungan dengan derajat deasetilasi $89 \%$. Bahan lain yang digunakan adalah PVA, asam asetat dan akuades. Beberapa peralatan yang digunakan antara lain spineret (suntikan ukuran 10 $\mathrm{ml}$ ), syringe ukuran outlet $0,5 \mathrm{~mm}$, electrospinner, FTIR (Perkin Elmer Spectrum One), hot plate stirrer, magnetic stirrer, viskometer (Brookfiled LV DV2T), timbangan, SEM (JEOL-JCM 6000).

\section{Pembuatan kitosan cangkang rajungan}

Kitosan yang digunakan pada penelitian ini dibuat dalam skala pilot menggunakan bahan baku cangkang rajungan (Syamdidi \& Wibowo, 2012; Wibowo, Gonzalo, Savant, Torres, 2007). Cangkang dipanaskan dalam larutan $\mathrm{NaOH}$ teknis 3,5\% (b/v) selama 2 jam pada suhu $70-80{ }^{\circ} \mathrm{C}$ lalu dicuci sampai netral. Selanjutnya, dilakukan proses demineralisasi menggunakan larutan $\mathrm{HCl}$ teknis dengan perbandingan cangkang kering dan $\mathrm{HCl}$ 1:1,5 (b/v) lalu dicuci kembali sampai netral. Tahapan selanjutnya adalah deasetilasi dengan memanaskan cangkang dalam larutan $\mathrm{NaOH}$ $60 \%$ suhu pada $110^{\circ} \mathrm{C}$ selama 8 jam. Kitosan kemudian dicuci sampai netral lalu dikeringkan dengan dijemur di bawah panas matahari. Parameter yang diamati untuk karakterisasi kitosan yang diperoleh adalah kadar air (BSN, 2006), kadar abu (BSN, 2006), derajat deasetilasi menggunakan metode ${ }^{1} H N M R$ Spectroscopy (Kasaai, 2009) dengan NMR ECS 400 $\mathrm{MHz}$ Jeol, viskositas (AOAC, 1995), dan analisis gugus fungsi (Khan, Peh \& Ch'ng, 2002) menggunakan spektrofotometer (FTIR Perkin Elmer Spectrum One).

\section{Penyiapan larutan kitosan-PVA}

Metode penyiapan larutan dan pembuatan serat nano kitosan-PVA mengacu pada hasil penelitian Panboon (2005). Larutan kitosan dan PVA disiapkan secara terpisah terlebih dahulu dengan menggunakan pelarut yang berbeda sebelum dicampur untuk mendapatkan larutan kitosan-PVA. Larutan 10\% PVA (w/v) disiapkan dengan cara melarutkan bubuk PVA ke dalam akuades menggunakan hot plate stirrerpada suhu $80{ }^{\circ} \mathrm{C}$ disertai pengadukan menggunakan magnetic stirrer hingga PVA larut dengan sempurna. Larutan kitosan disiapkan dengan melarutkan 2\% kitosan (w/v) ke dalam pelarut asam asetat $2 \%$ menggunakan hot plate stirrer disertai dengan pengadukan menggunakan magnetic stirrer hingga kitosan larut. Larutan kitosan dan PVA kemudian dicampur dengan perbandingan (dikembangkan dari Jia et al. 2007) 1:9 (v/v) (C1P9); 2:8 (v/v) (C2P8); 3:7 (v/v) (C3P7) dan 4:6 (v/v) (C4P6). Proses pencampuran larutan PVA ke dalam larutan kitosan berlangsung pada suhu $80^{\circ} \mathrm{C}$ sambil diaduk dengan magnetic stirrer hingga homogen.

\section{Pembuatan serat nano kitosan - PVA}

Pembuatan serat nano dilakukan menggunakan electrospinner dengan 3 kali ulangan. Masing-masing larutan dengan rasio campuran seperti yang telah dijelaskan sebelumnya (C1P9, C2P8, C3P7, C4P6) kemudian dimasukkan ke dalam syringe $10 \mathrm{ml}$ sebanyak $3 \mathrm{ml}$. Ukuran diameter syringe outlet adalah $0,5 \mathrm{~mm}$. Cairan dilewatkan pada media dengan arus listrik tegangan tinggi ( $15 \mathrm{kV}$ ) untuk mendapatkan serat. Di bagian samping electrospinnerterdapat kaca preparat yang ditempelkan ke aluminium foil yang berfungsi sebagai sample collector untuk serat yang dihasilkan. Jarak antara syringe dengan sample collector sepanjang $15 \mathrm{~cm}$. Waktu yang dibutuhkan dalam proses ini sekitar 2 jam.

Parameter yang diamati adalah viskositas (AOAC, 1995) dengan menggunakan Brookfield viscometer LV DV2T, analisis gugus fungsi berdasarkan metode 
Khan et al. (2002) terhadap kitosan, PVA, dan serat nano kitosan-PVA menggunakan spektrofotometer (FTIR Perkin Elmer Spectrum One) dan analisis struktur mikro dan diameter serat nano kitosan-PVA menggunakan SEM JEOL-JCM 6000 (Paipitak, Pornpra, Mongkontalang, Techitdheera \& Pecharapa 2011). Pengukuran diameter dilakukan terhadap 30 serat per frame dari hasil pengamatan analisis struktur mikro sesuai dengan kemampuan SEM JEOL-JCM 6000.

\section{HASIL DAN PEMBAHASAN}

\section{Karakteristik Kitosan}

Hasil analisis terhadap kitosan yang digunakan dalam penelitian ini dapat dilihat pada Tabel 1 yang dibandingkan dengan kitosan produksi Heppe $\mathrm{GmbH}$, Jerman (Struszczyk, 2002). Dari Tabel tersebut tampak bahwa secara keseluruhan kitosan yang digunakan dalam penelitian ini sesuai dengan tipikal karakteristik kitosan (kadar air, abu, dan DD) produksi Heppe $\mathrm{GmbH}$, Jerman untuk kitosan dengan kisaran viskositas 200-800 cPs. Perbedaan viskositas tampaknya berakibat pada tingkat toleransi terhadap kadar abu (Struszczyk, 2002). Pada kitosan dengan viskositas rendah K1 (200-300 cPs), kadar abu dipersyaratkan $<1 \%$, viskositas sedang K2 (400-600 cPs) 0,5-1\%, sedangkan viskositas tinggi K3 (600$800 \mathrm{cPs}$ ) adalah $<0,5 \%$. Kadar abu yang rendah menunjukkan kandungan mineral yang rendah sehingga mutu dan tingkat kemurnian kitosan akan lebih baik.

Dilihat dari kadar airnya, contoh kitosan cangkang rajungan yang digunakan dalam penelitian ini telah memenuhi kriteria kitosan Heppe GmbH Jerman (Tabel 1). Hal ini mengindikasikan bahwa proses pengeringan (penjemuran selama 4-6 hari) untuk menghasilkan kitosan telah mencukupi dan berjalan dengan baik (Saleh, Abdillah, Suherman, Basmal \& Indriati, 1994).

Di sisi lain, kandungan total nitrogen dapat digunakan untuk memberikan gambaran apakah proses pengolahan telah dapat menghasilkan kitosan. Secara matematis berdasarkan unsur penyusunnya, $\% \mathrm{~N}$ dalam $\mathrm{N}$-acetyl glucosamine (monomer kitin) sekitar 5,9\% dan akan mencapai 6,6\% jika 55-60\% dari monomer kitin telah mengalami deasetilasi menjadi glukosamin. Secara teoritis, kitin yang telah terdeasetilasi 55-60\% tersebut dapat dikategorikan sebagai kitosan, namun secara komersial dapat dikategorikan sebagai kitosan jika deasetilasi telah mencapai $70-75 \%$ (Wibowo, 2003) yang secara matematis setara dengan $\% \mathrm{~N}$ sebesar $6,8-6,9 \%$, dengan catatan bahwa $\mathrm{N}$ dari protein tidak diperhitungkan. Makin tinggi tingkat deasetilasinya maka akan semakin tinggi pula \%N. Berdasarkan hal ini maka kitosan yang digunakan dalam penelitian dengan \%N 7,23\% (Tabel 1) telah memenuhi kriteria kitosan komersial.

Variasi viskositas pada kitosan pada dasarnya ditentukan oleh panjang-pendeknya rantai kitosan yang

Tabel 1. Karakteristik kitosan

Table 1. Characteristics of chitosan

\begin{tabular}{lcccc}
\hline & Kitosan Contoh/ & \multicolumn{2}{c}{$\begin{array}{c}\text { Kitosan produksi Heppe GmbH, } \\
\text { Sample Chitosan }\end{array}$} & $\begin{array}{c}\text { Jerman/Chitosan from Heppe GmbH, } \\
\text { Germany }\end{array}$ \\
\cline { 3 - 5 } & & K1 & K2 & K3 \\
\cline { 3 - 5 } & $4.52 \pm 0.22$ & $<10$ & $<10$ & $<10$ \\
\hline Kadar air/Moisture (\%) & $0.48 \pm 0.03$ & $<1$ & $0.5-1$ & $<0.5$ \\
Kadar abu/Ash (\%) & $7.23 \pm 0.35$ & - & - & - \\
Total nitrogen/Nitrogen total (\%) & $89.06 \pm 0.97$ & $85-90$ & $85-90$ & $85-90$ \\
Derajat deasetilasi/Degree of deacetylation (\%) & $342.83 \pm 0.29$ & $200-300$ & $400-600$ & $500-800$ \\
Viskositas/Viscosity (cPs) & & &
\end{tabular}

Keterangan/Note:

*) Karakteristik kitosan Heppe $\mathrm{GmbH}$, Jerman (K1, K2,K3) yang berbeda viskositas (Struszczyk, 2002)/ Characteristics of chitosan from Heppe $\mathrm{GmbH}$, Germany (K1, K2, K3) with different viscosity based on Struszczyk (2002) 
berarti ditentukan oleh berat molekul (BM) kitosan. Makin panjang rantai kitosan berarti makin tinggi viskositas dan BMnya. Tingginya BM yang diiringi dengan tingginya DD mengindikasikan makin banyak gugus glukosamine yang tersedia untuk memfasilitasi reaksi. Akan tetapi, terdapat indikasi bahwa DD lebih berperan daripada BM dalam reaksi kitosan (Wibowo et al. 2007; Wibowo, 2014). Sampel kitosan yang digunakan dalam penelitian ini meskipun memiliki viskositas rendah namun memiliki DD yang tinggi sehingga memungkinkan bagi kitosan tersebut untuk berperan lebih baik dalam reaksinya sebagai serat nano. Selain itu, dalam proses pembuatan serat nano menggunakan teknik electrospinning tidak memerlukan kitosan dengan viskositas tinggi karena akan membuat proses electrospinning pada pembuatan serat nano menjadi lebih sulit (Roozbahani, Sultana, Ismail \& Nouparvar, 2013).

Derajat deasetilasi (DD) yang tinggi akan menyebabkan kitosan memiliki kesempatan lebih banyak untuk berinteraksi dengan senyawa lain (Wibowo, Velazquez, Savant \& Torres, 2005a; Wibowo, Savant, Cherian, Savage \& Torres, 2005b; Wibowo et al., 2007a; Wibowo et al., 2007b). Kitosan yang digunakan dalam penelitian ini memiliki DD $89,06 \pm 0,97$ (Tabel 1) yang mengindikasikan potensi interaksinya yang baik dengan senyawa lain. Derajat deasetilasi (DD) tersebut akan berpengaruh terhadap serat nano yang akan dihasilkan, di antaranya berpengaruh terhadap nilai kekuatan tarik serat yang dihasilkan. Semakin kecil nilai derajat deasetilasi kitosan yang digunakan maka akan menurunkan nilai kekuatan tariknya (Zheng, Du, Yu, Huang \& Zhang, 2001). Dari hasil penelitian Zheng et al. (2001) dapat diketahui bahwa penggunaan kitosan dengan derajat deasetilasi 84,5-90,2\% menghasilkan serat kitosan dengan nilai kekuatan tarik serat yang lebih baik dibandingkan dengan serat kitosan dari bahan baku yang memiliki DD 71,3-79,1\%. Dengan demikian, kitosan yang digunakan dalam penelitian ini diharapkan mampu menghasilkan serat nano yang baik.

\section{Karakteristik Nano Komposit Kitosan-PVA}

\section{Viskositas}

Hasil pengukuran viskositas dapat dilihat pada Tabel 2. Dari Tabel 2 tersebut tampak bahwa viskositas kitosan yang digunakan untuk membentuk komposit lebih rendah daripada viskositas PVA. Setelah dicampurkan, viskositas komposit yang dihasilkan lebih tinggi dari masing-masing penyusunnya. Semakin tinggi persentase PVA di dalam larutan komposit kitosan-PVA semakin tinggi viskositas komposit yang dihasilkan. Semakin tinggi persentase kitosan yang digunakan akan semakin rendah viskositas kompositnya. Viskositas tertinggi diperoleh dari komposit kitosan-PVA dengan perbandingan 1:9 (v/v) $(764,34 \pm 2,07 \mathrm{cPs})$ dan nilai viskositas terendah diperoleh dari campuran kitosanPVAdengan perbandingan 4:6 (v/v) $(552,00 \pm 1,20 \mathrm{cPs})$. Di dalam pencampuran kitosan dengan PVA akan terjadi interaksi ikatan hidrogen antara grup hydroxyl pada PVA dengan grup amin pada kitosan yang akan meningkatkan viskositas campuran dibandingkan viskositas masing-masing bahan (Panboon, 2005).

Nilai viskositas dari larutan akan berpengaruh terhadap serat nano yang terbentuk pada proses electrospinning. Viskositas yang terlalu rendah akan menyebabkan sampel mudah menetes dari jarum suntik pada saat proses electrospinning, sedangkan viskositas yang terlalu tinggi dapat menyebabkan serat sulit terbentuk (Mutia \& Eriningsih, 2012).

Tabel 2. Viskositas kitosan, PVA dan komposit Kitosan-PVA

Table 2. Viscosity of chitosan, PVA, and chitosan-PVA composite

\begin{tabular}{lc}
\hline \multicolumn{1}{c}{ Sampel/Sample } & Viskositas/Viscosity (cPs) \\
\hline Kitosan/chitosan & $342.83 \pm 0.29$ \\
PVA & $427.60 \pm 8.51$ \\
Komposit kitosan-PVA 1:9 (v/v)/Chitosan-PVA 1:9 composite $(\mathrm{V} / \mathrm{V})$ & $764.34 \pm 2.07$ \\
Komposit kitosan-PVA 2:8 $(\mathrm{v} / \mathrm{v}) /$ Chitosan-PVA 2:8 composite $(\mathrm{V} / \mathrm{V})$ & $725.05 \pm 5.60$ \\
Komposit kitosan-PVA 3:7 (v/v)/Chitosan-PVA 3:7 composite $(\mathrm{V} / \mathrm{v})$ & $658.40 \pm 3.67$ \\
Komposit kitosan-PVA 4:6 (v/v)/Chitosan-PVA 4:6 composite $(\mathrm{V} / \mathrm{V})$ & $552.00 \pm 1.20$ \\
\hline
\end{tabular}




\section{Gugus fungsi}

Hasil pengujian gugus fungsi dengan menggunakan spektrofotometer terhadap kitosan dan PVA serta komposit kitosan-PVA dengan berbagai rasio dapat dilihat pada Gambar 1. Pada spektra IR kitosan, muncul pita serapan pada panjang gelombang $3434 \mathrm{~cm}^{-1}$ yang menunjukkan adanya tumpang tindih dengan vibrasi rentangan gugus $-\mathrm{OH}$ dan $\mathrm{N}-\mathrm{H}$. Pita serapan pada bilangan gelombang $2918 \mathrm{~cm}^{-1}$ menunjukkan vibrasi rentangan $\mathrm{C}-\mathrm{H}$ pada $-\mathrm{CH}_{2}-$ alifatik. Hal ini diperkuat dengan adanya serapan vibrasi tekukan $-\mathrm{CH}_{2}$ - pada bilangan gelombang $1420 \mathrm{~cm}^{-1}$. Pada spektra IR kitosan, juga muncul pita serapan pada bilangan gelombang $1595 \mathrm{~cm}^{-1}$ yang menunjukkan vibrasi tekukan $\mathrm{N}-\mathrm{H}$ dari $\mathrm{NH}_{2}$. Rentangan C-O teridentifikasi di bilangan gelombang $1082 \mathrm{~cm}^{-1}$ dan $1034 \mathrm{~cm}^{-1}$, dan pita serapan pada bilangan gelombang $1152 \mathrm{~cm}^{-1}$ untuk rentangan C-O-C. Pada pengujian gugus fungsi untuk PVA diketahui bahwa pita serapan pada bilangan gelombang $1420 \mathrm{~cm}^{-1}$ menunjukkan adanya serapan vibrasi tekukan $-\mathrm{CH}_{2}$. Pita serapan pada bilangan gelombang $1711 \mathrm{~cm}^{-1}$ menunjukkan adanya residu grup asetil dan pita serapan pada bilangan gelombang $3368 \mathrm{~cm}^{-1}$ untuk rentangan gugus $-\mathrm{OH}$.

Interaksi antara kitosan dan PVA dalam serat nano dapat dideteksi dengan menggunakan FTIR. Menurut Yeh et al. (2006), FTIR merupakan metode yang mampu mendeteksi dengan baik interaksi intermolekular yang terjadi antara dua polimer. Dari Gambar 1 dapat diketahui bahwa spektrum serat nano komposit kitosan-PVA memiliki kemiripan dengan spektrum kitosan maupun PVA. Dengan penambahan kitosan pada larutan PVA, regangan gugus $\mathrm{OH}$ pada PVA menjadi lebih lebar. Sementara itu, regangan gugus $\mathrm{O}-\mathrm{H}$ dan $\mathrm{N}-\mathrm{H}$ pada kitosan mengalami penurunan pada zona frekuensi yang lebih rendah $\left(3399 \mathrm{~cm}^{-1}\right)$. Kedua hal tersebut menunjukkan adanya pembentukan ikatan hidrogen baru di antara molekulmolekul yang ada di dalam polimer. Hal ini sesuai

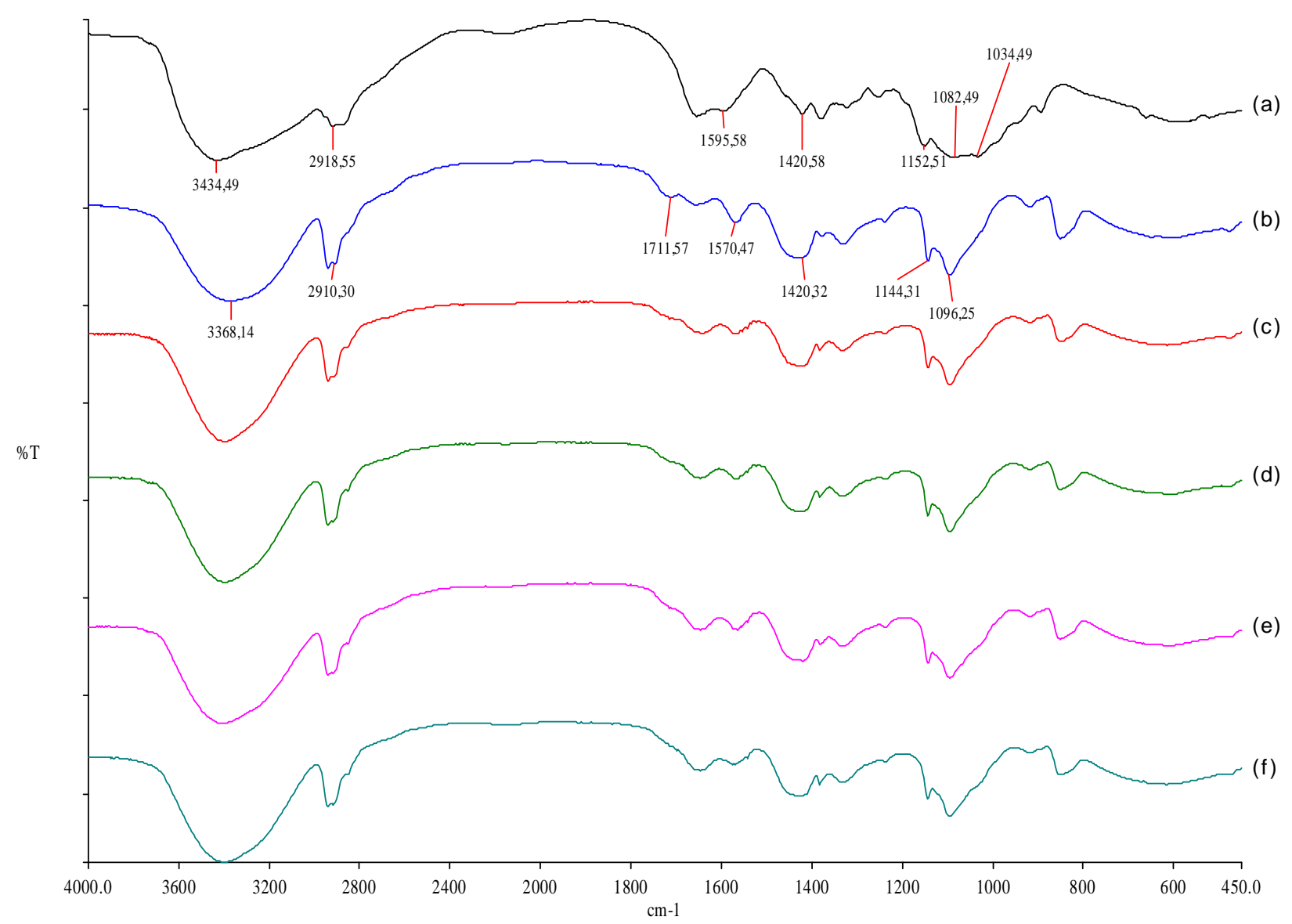

Gambar 1. Spektra FTIR kitosan (a), PVA (b), komposit kitosan-PVA C1P9 (c); C2P8 (d); C3P7 (e); C4P6 (f) Figure 1. FTIR spectra of chitosan (a), PVA (b), chitosan-PVA composite nano fiber C1P9 (c); C2P8 (d); C3P7 (e); C4P6 (f) 


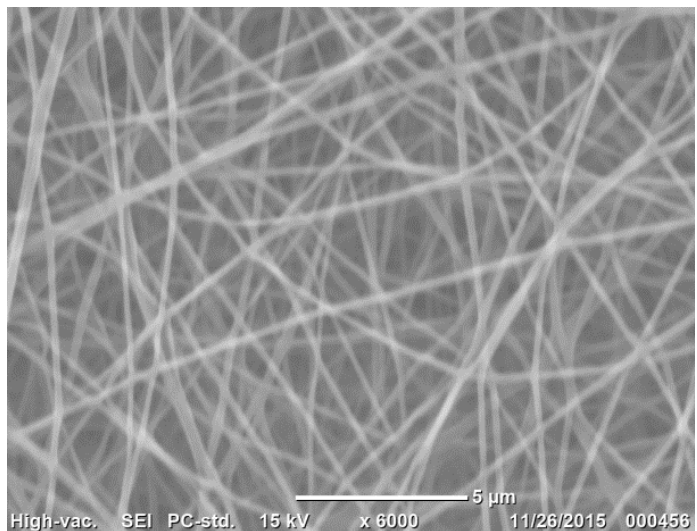

(a)

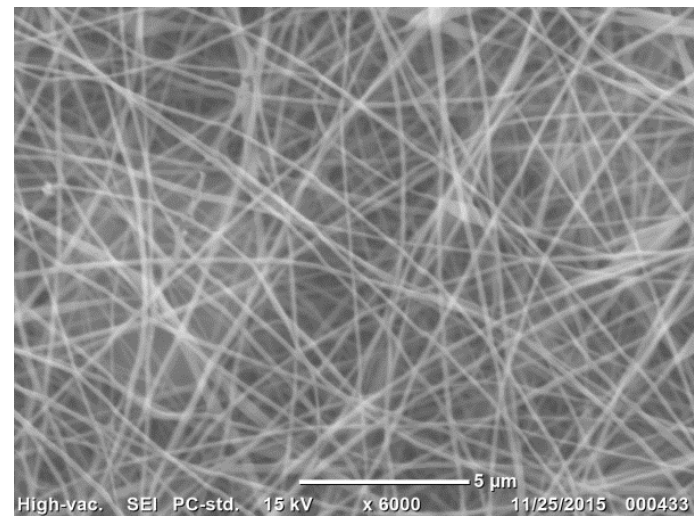

(c)

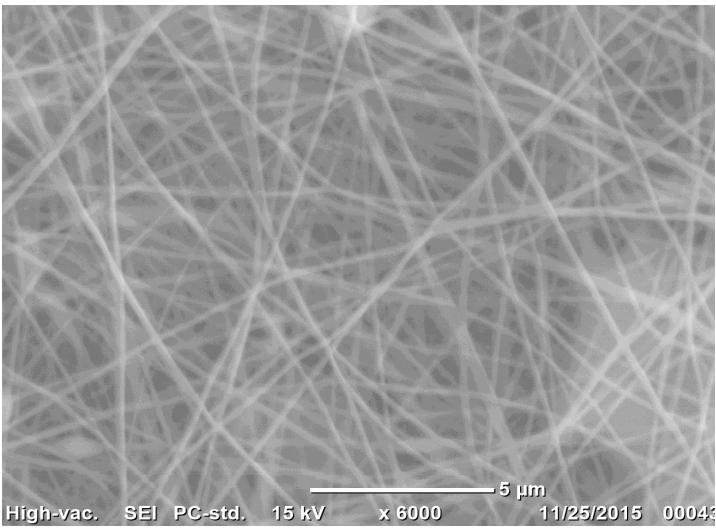

(b)

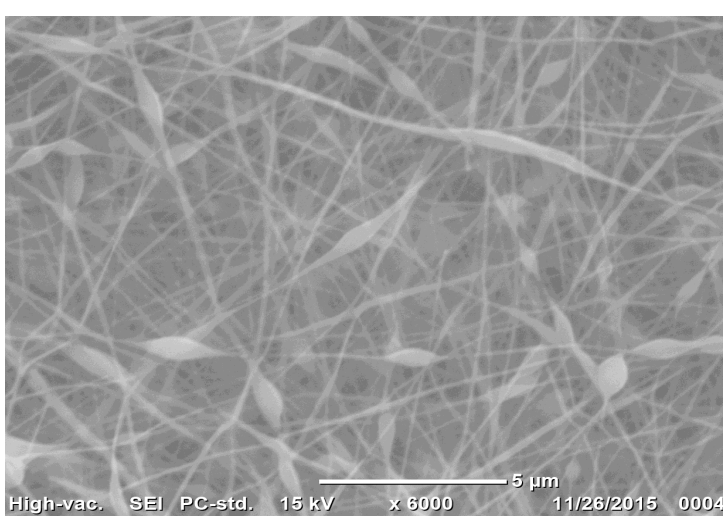

(d)

Gambar 2. Citra SEM serat nano komposit kitosan-PVA pada beberapa rasio campuran (a) 1:9; (b) 2:8; (c) $3: 7 ;$ (d) 4:6 (v/v) yang dibentuk menggunakan electrospinning

Figure 2. SEM image of chitosan-PVA composite nano fiber at different ratios of (a) 1:9; (b) 2:8; (c) 3:7; (d) 4:6 ( $V / v)$ formed by electrospinning

dengan hasil penelitian Zheng et al. (2001), yaitu penambahan PVA dalam larutan kitosan menyebabkan terjadinya pergeseran ke kanan panjang gelombang pada regangan gugus $\mathrm{O}-\mathrm{H}$ dan $\mathrm{N}-\mathrm{H}$ yang diduga disebabkan oleh adanya pembentukan ikatan hidrogen antara kitosan dan PVA.

\section{Struktur mikro serat nano komposit kitosan- PVA}

Hasil pengujian struktur mikro yang dilakukan terhadap serat nano komposit kitosan-PVA yang dihasilkan melalui proses electrospinning dapat dilihat pada Gambar 2.

Dari Gambar 2 dapat diketahui bahwa proses electrospinning pada tegangan $15 \mathrm{kV}$, diameter jarum $0,5 \mathrm{~mm}$ dan jarak $15 \mathrm{~cm}$ terhadap kitosan dan PVA telah dapat menghasilkan serat nano berbahan dasar kitosan dengan penambahan PVA yang berbeda sesuai komposisinya. Komposit kitosan-PVA 1:9 (v/ v) menghasilkan serat nano yang paling bersih dan hampir tidak ditemukan adanya beads (Gambar 2a). Beads mulai ditemukan pada serat nano dari komposit kitosan-PVA2:8 (v/v) (Gambar 2b) dan makin banyak beads pada komposit kitosan-PVA 4:6 (v/v) (Gambar 2d).

Penambahan PVA dalam larutan kitosan dimaksudkan untuk memperbaiki serat nano yang dihasilkan. Peningkatan jumlah PVA hingga 90\% dalam komposit dapat meningkatkan viskositas (Tabel 2) yang berpengaruh pada kemudahan dalam pembentukan serat nano dan memperbaiki serat nano yang dihasilkan. Hasil penelitian Jia et al. (2007) menunjukkan hasil serupa, yaitu makin tinggi PVA yang ditambahkan akan makin mengurangi beads yang terbentuk dan menghasilkan serat yang lebih seragam. Peningkatan viskositas menunjukkan terjadinya peningkatan massa molekul relatif dari 
polimer dalam larutan, yang akan meningkatkan ketahanan tarik dari polimer, sehingga dalam proses electrospinning kemampuan polimer membentuk serat tanpa adanya beads akan meningkat (Winiati, Judawisastra \& Ramadhianti, 2012).

\section{Diameter serat nano komposit kitosan-PVA}

Sebaran diameter serat nano kitosan-PVA hasil pengukuran dengan SEM JEOL-JCM 6000 tampak seperti pada Gambar 3. Serat nano kitosan-PVA dengan perbandingan $1: 9 ; 2: 8 ; 3: 7$; dan $4: 6(\mathrm{v} / \mathrm{v})$ memiliki rata-rata diameter serat masing-masing sekitar $302,77 \pm 80,45 \mathrm{~nm} ; 257,17 \pm 54,14 \mathrm{~nm}$; $334,90 \pm 70,85 \mathrm{~nm}$; dan $200,39 \pm 6,36 \mathrm{~nm}$. Nilai ratarata ini dihitung dari rata-rata $30 x$ pengukuran diameter. Dalam dunia perdagangan, serat nano
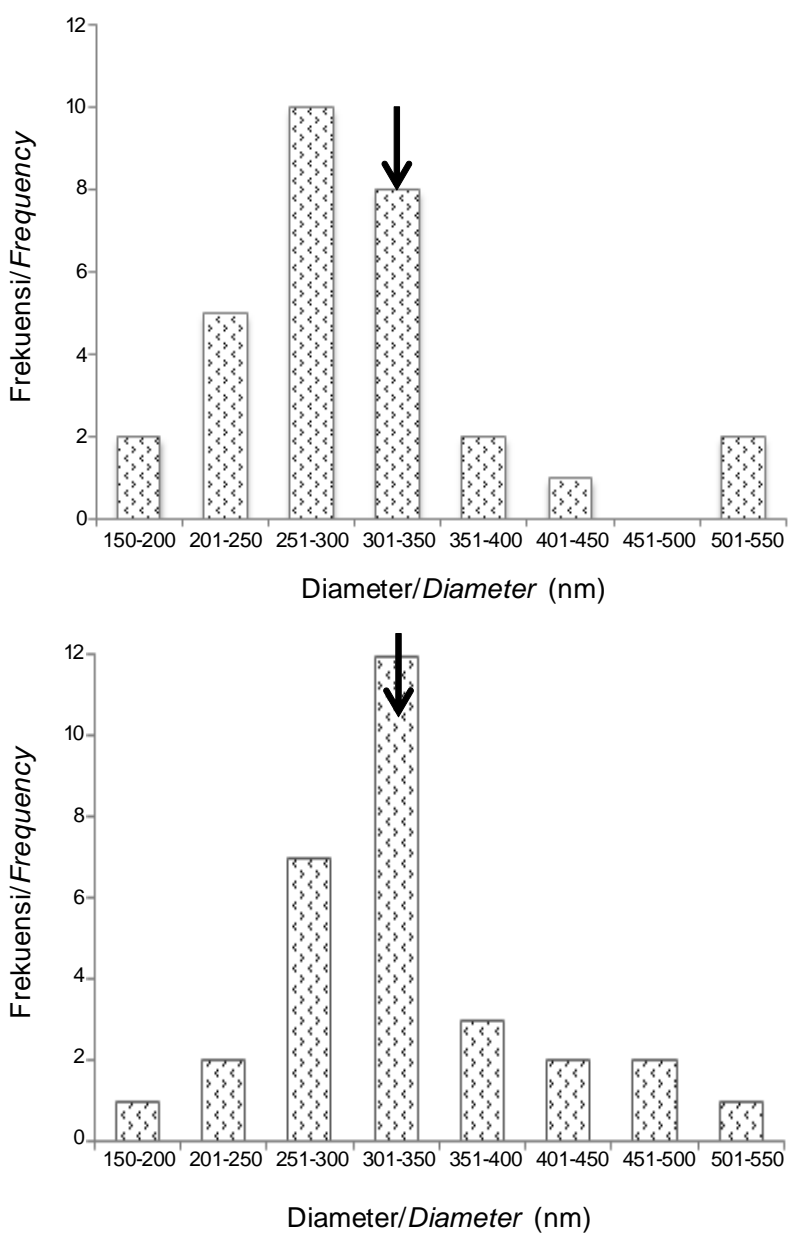

adalah serat yang mempunyai diameter kurang dari $500 \mathrm{~nm}$ (0,5 mikron), sedangkan serat yang telah diproduksi dan diperdagangkan mempunyai diameter antara $50 \mathrm{~nm}$ sampai $300 \mathrm{~nm}$ (Lee, 2007). Dengan demikian dapat diketahui bahwa diameter serat nano yang dihasilkan dalam penelitian ini telah memenuhi persyaratan serat nano yang diperdagangkan.

Dari Gambar 3 dapat diketahui bahwa distribusi ukuran diameter serat nano yang dihasilkan masih belum homogen dan mediannya cenderung lebih kecil dari nilai rata-rata, kecuali untuk komposit kitosanPVA3:7 (v/v) yang memiliki nilai rata-rata sama dengan mediannya. Komposit kitosan-PVA $1: 9$ (v/v) mempunyai nilai median $288 \mathrm{~nm}$ (rata-rata 302,77 $\mathrm{nm}$ ), komposit kitosan-PVA 2:8 (v/v) mempunyai median sama dengan nilai rata-rata $(257,17 \mathrm{~nm})$, komposit kitosan-PVA3:7 (v/v) memiliki median 330
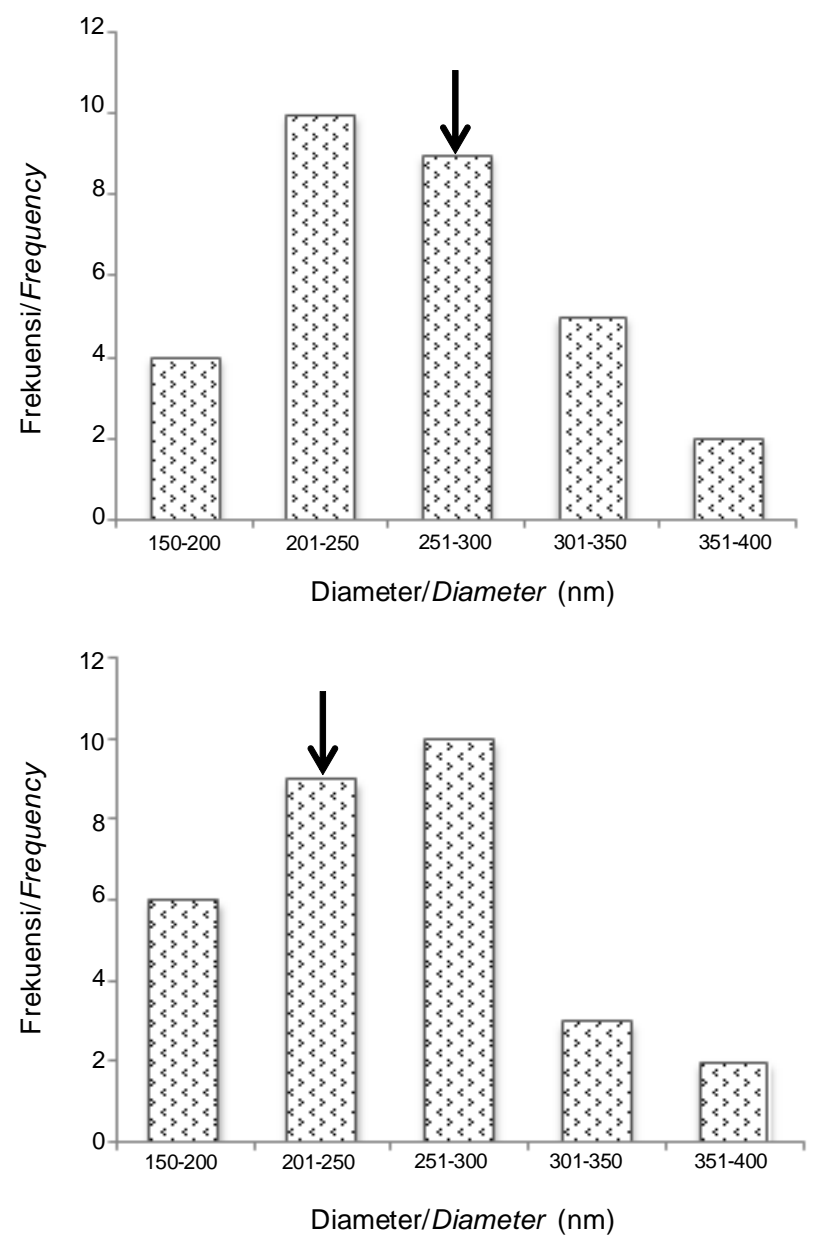

Gambar 3. Sebaran diameter serat nano komposit kitosan - PVA (tanda panah menunjukkan posisi nilai ratarata diameter serat nano) a. kitosan-PVA 1:9 (v/v), b. kitosan-PVA 2:8 (v/v), c. kitosan-PVA 3:7 $(\mathrm{v} / \mathrm{v})$, d. kitosan-PVA 4:6 ( $/ / \mathrm{v})$

Figure 3. Distribution of diameter of kitosan-PVA composite nanofiber (arrow showed the average of nano fiber diameter) a. chitosan-PVA 1:9 (V/V), b. chitosan-PVA 2:8 (V/V), c. chitosan-PVA 3:7 ( V/V), d. chitosan-PVA 4:6 ( $v / v)$ 
$\mathrm{nm}$ (rata-rata 334,90 nm), dan komposit kitosan-PVA 4:6 (v/v) mempunyai median $199 \mathrm{~nm}$ (rata-rata 200,39 $\mathrm{nm})$.

Untuk komposit kitosan-PVA 1:9(v/v), distribusi ukuran yang paling banyak terdapat pada diameter serat dengan ukuran 251-300 nm dan 301-350 nm. Sedangkan untuk perlakuan kitosan-PVA 3:7(v/v), distribusi ukuran yang paling banyak terdapat pada diameter serat dengan ukuran 301-350 nm. Distribusi ukuran diameter serat nano yang dihasilkan untuk perbandingan kitosan-PVA 2:8 (v/v) dan 4:6 (v/v) lebih homogen dibandingkan dengan 2 perlakuan lainnya. Hal ini dapat dilihat dari jumlah sebaran ukuran diameter serat yang lebih sedikit dibandingkan dengan perlakuan lainnya. Untuk perlakuan kitosan-PVA 2:8 (v/v), distribusi ukuran yang paling banyak terdapat pada diameter serat dengan ukuran 201-250 nm dan 251-300 nm. Sedangkan untuk perlakuan kitosan-PVA 4:6 (v/v), distribusi ukuran yang paling banyak terdapat pada diameter serat dengan ukuran 150-200 nm dan 201-250 nm. Berdasarkan hasil penelitian ini dan penelitian lain sebelumnya (Jia et al. 2007), keseragaman ukuran diameter serat nano menggunakan electrospinning ini antara lain dipengaruhi oleh rasio kitosan-PVAdan voltase. Rasio kitosan-PVA dan voltase juga berpengaruh terhadap sedikit banyaknya beads yang terbentuk.

\section{KESIMPULAN}

Serat nano yang dihasilkan dari kitosan limbah rajungan-PVA pada penelitian ini telah memenuhi persyaratan serat nano yang diperdagangkan. Viskositas larutan serat nano tersebut semakin tinggi seiring peningkatan jumlah PVA di dalam larutan campuran tersebut. Sedangkan peningkatan jumlah kitosan dalam larutan campuran kitosan-PVA menghasilkan serat nano dengan butiran-butiran beads yang lebih banyak dibandingkan dengan serat nano dari larutan campuran dengan kadar kitosan yang lebih sedikit. Interaksi intermolekular PVA dan kitosan melalui ikatan hidrogen meningkatkan kemampuan campuran kitosan-PVA dalam menghasilkan serat nano pada proses electrospinning.

\section{DAFTAR PUSTAKA}

[AOAC].Official Methode of Analysis of Analytical Chemist (1995). AOAC International. UK. Editor Cunniff PA. Elsevier Science Ltd.

[BSN]. Badan Standardisasi Nasional. (2006). Cara Uji Kimia. Jakarta: Badan Standardisasi Nasional. 11 $\mathrm{hlm}$.
Brown, P. J., \& Stevens, K. (2007). Nano Fiber and Nano Technology in Textiles. The Textile institute, Woodhead Pub. Ltd., Cambrige.

Cai, Z. X., Mo, X. M., Zhang, K. H., Fan. L. P., Yin, A. L., He, C. L., \& Wang, H.S. (2010). Fabrication of Chitosan/ Silk Fibroin Composite Nanofibers for Wounddressing Applications. Int. J. Mol. Sci. 11, 3529-3539.

Dai, T., Tanaka, M., Huang, Y-Y., \& Hamblin, M. R. (2011). Chitosan preparations for wounds and burns: antimicrobial and wound-healing effects. Expert Rev. Anti Infect. Ther., 9(7), 857-879.

Gessner, G., \& Hawley, (1981), The condensed chemical Dictonary, Tenth Edision, Vab Nostrand Reinhold Company, New York.

Herdiawan, H., Juliandri, \& Nasir, M. (2013). Pembuatan dan karakterisasi co-pvdf nanofiber komposit menggunakan metode elektrospinning. Prosiding Seminar Nasional Sains dan Teknologi Nuklir PTNBR - BATAN. 110-116.

Hoffman, A.S., (2002). Hydrogels for biomedical applications. Adv. Drug Delivery Rev., 43, 3-12.

Jayakumar, R., Prabaharan, M., Nair, S. V., \& Tamura, H. (2010). Novel chitin and chitosan nanofibers in biomedical applications. Biotechnology Advances., 28(1), 142-150.

Jayaraman, K., Kotaki, M., Zhang, Y.Z., Mo, X.M., \& Ramakrishna, S. (2004). Recent advances in polymer nanofibers. J. Nanosci. Nanotechnol., 4, 52-65.

Jia, Y. T., Gong, J., Gu, X. H., Kim, H. Y., Dong, J., \& Shen, X. Y. (2007). Fabrication and characterization of poly (vinyl alcohol)/chitosan blend nano fibers produced by electrospinning method. Carbohydrate Polymers, 67, 403-409.

Jiang, S., Liu, S., \& Feng, W. (2011). PVA hydrogel properties for biomedical application. Journal Of The Mechanical Behavior Of Biomedical Materials, 4, 1228-1233.

Judawisastra, H., Winiati, W., \& Ramadhianti, P.A. (2012). Pembuatan Serat Nano Kitosan Tanpa Beads melalui Penambahan PVA dan HDA, Jurnal IImiah Arena Tekstil, 27(2), 63-70.

Kasaai, M. R. (2009). Various methods for determination of the degree of $\mathrm{N}$-acetylation of chitin and chitosan. Journal of Agric. Food. Chem., 57, 1667-1676.

Khan, T. A., Peh, K. K., \& Ch'ng, H. S. (2002). Reporting Degree of Deacetylation Values of Chitosan: The Influence of Analytical Methods. Journal of Pharmacy and Pharmaceutical Science, 5, 205-212.

Kim, H. W., Lee, H. H., \& Knowles, J. C. (2006). Electrospinning biomedical nanocomposite fibers of hydroxyapatite/ poly(lactic acid) for bone regeneration. Journal of Biomedical Materials Research, Part A DOI 10.1002. 643-649.

Kumbar, S.G., James, R., Nukavarapu, S.P., \& Laurencin, C.T. (2008). Electrospun nanofiber scaffolds: engineering soft tissues. Biomed. Mater., 3, 034002. $15 \mathrm{pp}$.

Lee, E. H., Uyama, H., \& Kwon, O. H., (2009). Fabrication of ultrafine fibers of poly(c-glutamic acid) and its 
derivative by electrospinning. Polym. Bull., 63, 735742, DOI 10.1007/00289-009-0112-5.

Lee, S. (2007). Use Electrospun Nanofiber web for Proective Textile Material As Barrier to Liquid Penetration. Textile research journal, 77(9).

MA, G. P., Yang, D. Z., \& Chen, B. L., (2010). Preparation and characterization of composite fibers from organic-soluble chitosan and poly-vinylpyrrolidone by electrospinning. Front. Mater. Sci. China, 4(1): 6469, DOI 10.1007/s11706-010-0012-5.

Mutia, T., \& Eriningsih, R. (2012). Penggunaan webs serat alginat/polivinil alcohol hasil proses elektrospining untuk pembalut luka primer. Jurnal Riset Industri, 6(2), 137-147.

Paipitak, K., Pornpra, T., Mongkontalang, P., Techitdheera, W., \& Pecharapa, W. (2011). Characterization of PVAChitosan Nanofibers Prepared by Electrospinning. Procedia Engineering, 8, 101-105.

Panboon, S., (2005). Electrospinning of Poly(Vinyl Alcohol)/Chitosan Fibers for Wound Dressing Applications. Thesis. King Mongkut's Institute of Technology North Bangkok, ISBN 974-19-0476-2.

Paradossi, G., Cavaleri, F., Chiessi, E., Spagnoli, C., Cowan, M.K., (2003). Poly(vinyl alcohol) as versatile biomaterial for potential biomedical applications. J. Matter. Sci. Mater. Med., 14, 687-691.

Ramakrishna, S., Fujihara, K., Teo, W-E., Lim, T-C., \& Ma, Z. (2005). An Introduction to Electrospinning and Nanofibers. World Scientific Publishing Co. Pte. Ltd. Singapore.

Roozbahani, F., Sultana, N., Ismail, A.F., \& Nouparvar, H. (2013). Effects of Chitosan Alkali Pretreatment on the Preparation of Electrospun PCL/Chitosan Blend Nanofibrous Scaffolds for Tissue Engineering Application. Journal of Nanomaterials Volume 2013, Article ID 641502, 6.

Saleh, M. R., Abdillah, R., Suherman, E., Basmal, J., \& Indriati, N. (1994). Pengaruh Suhu, Waktu dan Konsentrasi Pelarut pada Ekstraksi Kitosan dari Limbah Pengolahan Udang Beku Terhadap Beberapa Parameter Mutu Kitosan. Jurnal Pasca Panen Perikanan, 81,30-43.

Struszczyk, M.H. (2002). Chitin and Chitosan. POLIMERY 2002,47, nr 6. 396-403.

Sun, K., \& Li, H. Z. (2011). Preparations, properties and applications of chitosan based nanofibers fabricated by electrospinning. eXPRESS Polymer Letters, 5(4), 342-361.

Syamdidi \& Wibowo, S. (2012). Penentuan Konsentrasi $\mathrm{HCl}$ dan Waktu Ekstraksi Optimum pada Proses
Demineralisasi Cangkang Rajungan, Portunus sp. terhadap Produksi Khitin Skala Pilot Plant. Prosiding Seminar Nasional Tahunan IX Hasil Penelitian Perikanan dan Kelautan Tahun 2012. Jurusan Perikanan Fakultas Pertanian UGM. Yogyakarta, Oktober 2012. Kode PB-03. ISBN: 978-602-9221-152

Wahyudi, T., \& Sugiyana, D. (2011). Pembuatan serat nano menggunakan metode electrospinning. Arena Tekstil. 26(1), 1-60.

Wibowo, S., Gonzalo, V., Savant, V., \& Torres, J. A. (2007). Effect of chitosan type on protein and water recovery efficiency from surimi wash water treated with chitosan-alginate complexes. Bioresource Technology. (ISSN : 0960-8524), 98(3), 539-545.

Wibowo, S., Velazquez, G., Savant, V., \& Torres, J. A. (2005a). Surimi wash water treatment for protein recovery: effect of chitosan-alginate complex concentration and treatment time on protein adsorption. Bioresource Technology, 96(6),665-71.

Wibowo, S. (2003). Surimi Wash Water Treatment by Chitosan-Alginate Complexes: Effect of Molecular Weight and Degree of Deacetylation of Chitosan and Nutritional Evaluation of Solids Recovered by the Treatment. [Dissertation]. Oregon State University, USA.

Wibowo, S. (2014). Pengaruh Berat Molekul dan Derajad Deasetilasi Kitosan dari Kulit Udang terhadap Recovery Protein dari Limbah Cair Pengolahan Surimi Prosiding Seminar Nasional Tahunan XI Hasil Penelitian Perikanan dan Kelautan, 30 Agustus 2014

Wibowo S., Savant V., Cherian G., Savage T. F., Velazquez, G., \& Torres, J.A. (2007a). A Feeding Study to Assess Nutritional Quality and Safety of Surimi Wash Water Proteins Recovered by a Chitosan-Alginate Complex. J. Food Sci., 72(3), S179-S184.

Wibowo, S., Savant, V., Cherian, G., Savage, T. F., \& Torres J. A. (2005b). Evaluation as a Feed Ingredient of Surimi Wash Water Protein Recovered Using a Chitosan-Alginate Complex. Journal of Aquatic Food Product Technology, 14(1), 55-72.

Wibowo, S., J. Basmal, Sugiono, Syamdidi, Octavia, D. A., \& Dwiyitno. (2007). Laporan Teknis Penelitian Khitin dan Khitosan. Balai Besar Riset Pengolahan Produk dan Bioteknologi Kelautan dan Perikanan. Jakarta.

Yeh, J. T., Chen, C. L., Huang, K. S., Nien, Y. H., Chen, J. L., \& Huang, P. Z. (2006). Synthesis, characterization, and application of PVP/chitosan blended polymers, Journal of Applied Polymer Science. 101(2), 885-891.

Zheng, H., Du Y., Yu, J., Huang, R., \& Zhang, L. (2001). Preparation and Characterisation of Chitosan/ Poly(vinyl alcohol) Blend Fibers. Journal of Applied Polymer Science, 80, 2558-2565. 